Borneo Journal of Sciences \& Technology, 4(1): 80-90

DOI: http://doi.org/10.35370/bjost.2022.4.1-12

e-ISSN: 2672-7439

(C) 2018, UTS Publisher.

Submitted: $20^{\text {th }}$ December $2021 \quad$ Accepted: $20^{\text {th }}$ January $2022 \quad$ Published: $31^{\text {st }}$ January 2022

\title{
A Principle Framework for Determining Timely Completion of Building Projects in Public Tertiary Institutions in Bauchi and Gombe State, Nigeria
}

\author{
${ }^{1}$ Suleiman Shehu, ${ }^{2}$ Rabiu Shehu \\ ${ }^{1}$ Department of Quantity Surveying, Faculty of Environmental Technology, Abubakar Tafawa Balewa \\ University Bauchi PMB 0248, Bauchi-Nigeria \\ ${ }^{2}$ Department of Building Technology, Faculty of Environmental Technology, Abubakar Tafawa Balewa \\ University Bauchi PMB 0248, Bauchi-Nigeria
}

\begin{abstract}
Building projects embarked upon in most public tertiary institutions in Nigeria were reported to have experienced delay in completion. The issue of poor completion of building projects is alarmingly global. Thus, this study aims at developing a principle framework for determining timely completion of building projects in public tertiary institutions in Bauchi and Gombe State, Nigeria. A total of 170 sample questionnaires were randomly distributed to four public tertiary institutions in Bauchi and Gombe state, Nigeria. Construction professionals with working affiliation with the clients, consultants and contractors were the respondents of the study. SPSS software was used to carry out both descriptive and inferential analysis in form of frequencies, percentages, mean scores, standard deviations, regression and one sample t-test. Findings revealed that communication and teamwork, monitoring and evaluation, planning, due process in award of contract, involvement of stakeholders, due availability of finance, and suitable construction method were the most relevant factors of timely completion. Furthermore, effective management, effective public procurement procedures and stakeholders' engagement inputs with P-values $0.000<0.05$ are the principle determinants of timely completion of building projects in public tertiary institutions in Bauchi and Gombe State, Nigeria with $21.8 \%$ increased cause-effects. In conclusion, timely completion is an essential success indicator of building projects in public tertiary institutions. Hence, there is need for a managerial synergy approach and adherence with all the laid down public procurement procedures and engaging stakeholders in order to enhance project completion on schedule.
\end{abstract}

Keywords: Building projects, determinants, Nigeria, public tertiary institutions, timely completion

\section{INTRODUCTION}

In the construction sector timely completion of buildings within estimated budget and agreed quality requirement has remained one of the critical goals set by stakeholders over the years due to unabated poor performance. According to Bowen et al, [1] timely completion of a construction project is frequently seen as a major criterion of project success by clients, contractors and consultants alike. Most building construction, remodeling, expansion and adaptation projects embarked upon in most public tertiary institutions of learning in Nigeria were reported to have experienced delay in completion which has adverse effect in achieving the planned schedule objectives leading to cost overrun, quality issues due to deterioration and exposure of components over time, disaffection among stakeholders, dissatisfaction by client and potential users amidst host of other problems. A research conducted by the Chartered Institute of
Building some years ago came to the conclusion that the quality of time management on construction projects is generally poor [2]. The issue of poor completion of building projects seems to be alarmingly global. For instance, as reported in Nigeria, seven out of ten projects suffered delays during their execution [3]; [4]. Some factors hampering on timely completion of building projects in public tertiary institutions in Nigeria might not be far from managerial, technical, political, contractual, act of nature among others etc. For instance, in universities it was reported that at times contractors are nominated to the university procurement entities by directors and top government functionaries without following the prescribed bidding and evaluation procedures [5];[6]. However, excellence in the procurement processes is essential in order to ensure good outcome in any project [7]. As such, poor management, poor adherence with public procurement procedures and poor engagement of stakeholders are capable of breeding problems leading to poor timely

Corresponding Author: Suleiman Shehu, Abubakar Tafawa Balewa University Bauchi, email:ssuleiman088@gmail.com 


\section{A Principle Framework for Determining Timely Completion of Building Projects in Public Tertiary Institutions in Bauchi and Gombe State, Nigeria}

completion of building projects in public tertiary institutions in Nigeria.

Though, few attempts were made in the past, for instance: Adeagbo et al., [8] studies application of Henry Fayol principles of management in the management of human resources in construction projects in four tertiary institutions in Bauchi state. Shehu [9] identified principles, processes and practices in his study through reviewing time management factors in construction project delivery. Shehu et al., [2] in their studies assessed the level of adherence with the processes of time management in construction project delivery in two tertiary institutions in Gombe state. Gambo et al., [10] in their studies assessed TETFUND project at Ahmadu Bello University Zaria in Kaduna state, Nigeria and discovered that $43 \%$ were not completed within planned cost, time and quality. In Africa, Kariungi [11] observed that procurement delays and timely availability of funds were the main factors that influenced the timely completion of Kenya Power and Lightening Company project. it has been observed during a pilot site survey in some selected public tertiary institutions in northern Nigeria prior to this study that only few building projects were seen to have been completed within schedule from the date of mobilization to site, majority were completed beyond the agreed schedule date while others were abandoned years after mobilization to site. Therefore, in light of the aforementioned studies and issues observed, this study is an improvement due to emergent trend overtime with the aim of developing a principle framework for determining timely completion of building projects in public tertiary institutions in Bauchi and Gombe State, Nigeria with a view to improving on efficient delivery of construction project in Nigeria, and the objectives are: to assess principle determining factors and their effects on timely completion of building projects in the study areas.

\section{LITERITURE REVIEW}

This section reviews literature to bring to light more on the independent and dependent variables, hypotheses and the proposed conceptual framework of the study.

\section{Building Projects and Facilities in Tertiary Institutions}

Tertiary institutions are the third level or postsecondary school learning environment that supports academic and research activities. In the Nigerian perspective they include: Universities, Polytechnics, Mono-technics, Colleges of educations and Academic research institutions. They are established by the government and private entities. Major buildings and facilities in a well-established tertiary institution of learning are: Administrative complex and office blocks, classrooms, lecture halls, laboratories, libraries, auditoriums, student hostel accommodations and staff quarters, medical centers, ICT centers. Others are student business centers, firefighting stations and link roads among others etc. in addition, the facilities are characterized by new building constructions, remodeling and expansion of existing facilities. Table 1 present the list of public tertiary institutions established by the state and federal government in Bauchi and Gombe state. In Nigeria about $70 \%$ of building construction projects and facilities found in most public tertiary institutions are funded by the federal government donor agencies in form of intervention initiative towards improving education output. For example, some of the funding agencies are: Tertiary Educational Trust Fund (TETFUND), Central Bank of Nigeria $(\mathrm{CBN})$ and Petroleum Development Trust Fund (PDTF) [5]. Though, few of the projects were being funded by individuals and private corporations as part of their corporate social responsibilities.

Table 1: List of Public Tertiary Institutions Situated in Bauchi and Gombe State, Nigeria

\begin{tabular}{|l|l|}
\hline \multicolumn{1}{|c|}{ Bauchi state Universities } \\
\hline \multicolumn{1}{|c|}{ Gombe state } \\
\hline $\begin{array}{l}\text { Abubakar Tafawa Balewa University Bauchi, Bauchi } \\
\text { State }\end{array}$ & Federal University of Kashere, Gombe State \\
\hline Bauchi State University, Gadau & Gomebe State University, Gombe \\
\hline $\begin{array}{l}\text { *Federal University of Health, Nutrition And Medical } \\
\text { Sciences Azare }\end{array}$ & $\begin{array}{l}\text { Gombe State University of Science And Technology } \\
\text { Kumo }\end{array}$ \\
\hline \multicolumn{2}{|c|}{ Polytechnics } \\
\hline Federal Polytechnic Bauchi Colleges of Education/ Special Colleges \\
\hline Abubakar Tatari Ali Polytechnic Bauchi & *Federal Polytechnic Kaltungo \\
\hline \multicolumn{2}{|c|}{ Collegation (Technical) Gombe } \\
\hline *Federal College of Education (Technical) Jama'are & Federal College of Education \\
\hline College of Education Azare & College of Education Billiri \\
\hline
\end{tabular}


A Principle Framework for Determining Timely Completion of Building Projects in Public Tertiary Institutions in Bauchi and Gombe State, Nigeria

\begin{tabular}{l}
\hline College of Agriculture Bauchi \\
\hline $\begin{array}{l}\text { Adamu Tafawa Balewa College of Education (Special) } \\
\text { Kangere, Bauchi }\end{array}$ \\
\hline \multicolumn{2}{|c|}{ School of Hea } \\
\hline Bauchi State School of Nursing And Midwifery \\
\hline Bauchi State College of Health Technology Ningi \\
* Approved for establishment \\
Source: Adapted from, NUC [12], Gombe, Bauchi state, \\
Principle Determining Factors and Project Timely \\
Completion
\end{tabular}

Principles are fundamental factors capable of influencing success if applied and adhered to in decision making. In addition, principles are established through observations, practice and long-term management experience [8]. Employing relevant processes, managing human resources and activities are essential towards timely completion of building projects. Adherence with the processes of time management most especially monitoring and controlling project schedule, estimating resource requirement for activities and developing schedule of the project are crucial for effective construction project delivery [2]. Correct or near accurate project schedule estimate is essential towards timely completion of building projects. The most prudent approach for avoiding delay of a construction project is to prepare a comprehensive and project-appropriate schedule and to maintain that schedule throughout the duration of the project [14]. In his study of Kenya power and lightening company, Kariungi [11] identified: availability of funds, procurement, climatic factors, project planning tools, stakeholders and managerial skills as determinant of timely completion of project.

A robust project financing and procurement mechanism put in place like construction method, contractual arrangement, contractors selected to execute the projects in public tertiary institutions are vital in achieving successful project delivery. Bashir and Akinola [15], posited that execution of building projects is being continuously characterized by delay, time and cost overrun, and in some extreme cases abandonment which could be connected at a greater extent to problems emanating from projects finance. For instance, in the UK in a survey by the Chartered Institute of Building [CIOB] [16], they report that of the $94 \%$ of respondents that have experienced delay in projects delivery, $49 \%$ seems to believe the chosen procurement method directly led to the time overruns. In addition, $64 \%$ display the feeling that a more transparent procurement process will benefit the
Federal College of Horticultural Technology Dadin-Kowa

Federal College of Hoticultural Technology Dadin-Kowa

Health Sciences

Gombe State School of Nursing And Midwifery

Gombe State College of Health Technology, Kaltungo

nd Federal Ministry of Education Archives [13].

construction industry. Project procurement management includes the processes necessary to purchase or acquire products, services, or results needed from outside the project team [17].

In addition, it involves the management and control processes required to develop and administer agreements such as contracts, purchase orders, memoranda of agreements, or internal service level agreements. According to UNDP [18] monitoring can be defined as the ongoing process by which stakeholders obtain regular feedback on the progress being made towards achieving their goals and objectives, while evaluation is a rigorous and independent assessment of either completed or ongoing activities to determine the extent to which they are achieving the stated objectives and contributing to decision making.

Project stakeholders' engagement and continuous cooperation is an essential determining factor in achieving timely completion of building projects. Project stakeholder management includes the processes required to identify the people, groups, or organizations that could impact or be impacted by the project, to analyze stakeholder expectations and their impact on the project, and to develop appropriate management strategies for effectively engaging stakeholders in project decisions and execution [17]. For instance, in Rwanda, Kobusingye et al., [19] observed that stakeholders' involvement in projects identification, planning, implementation and review has significant cause effects in the project outcome. In addition, failure to involve the key stakeholders in the initial and planning stages of the project cycle led to project delay. Planning is the process of setting goals, developing strategies, outlining the implementation arrangements and allocating resources to achieve those goals [18].

Timely completion entails a situation where projects are accomplished within contractually agreed schedule, budget, and to a degree of agreed quality. Timely delivery of construction project should be the business of every construction stakeholder's-client, consultants and contractors per se [2]. 


\section{A Principle Framework for Determining Timely Completion of Building Projects in Public Tertiary Institutions in Bauchi and Gombe State, Nigeria}

\section{Hypothesis of the Study}

Hypothesis is a presumptive statement of some sort of relationship between variables of a research which may or may not be true after analysis. According Oso and Onen [20] hypothesis is a proposal about a solution to a problem. In order to further achieve the aim of the study, the following null hypotheses as presented in
Table 2 were proposed. However, in the Alternative hypotheses, principle determinant factors: effective management, effective public procurement and stakeholders engagement are relevant in determining timely completion of building projects in the study area.

Table 2: Null Hypotheses for the Study

\begin{tabular}{|l|l|}
$\mathrm{HO}_{1}$ & $\begin{array}{l}\text { Effective management factors are not relevant in determining timely completion of building project in } \\
\text { public tertiary institutions in Bauchi and Gombe state, Nigeria. }\end{array}$ \\
\hline $\mathrm{HO}_{2}$ & $\begin{array}{l}\text { Effective public procurement procedures are not relevant in determining in timely completion of } \\
\text { building project in public tertiary institutions in Bauchi and Gombe state, Nigeria. }\end{array}$ \\
\hline $\mathrm{HO}_{3}$ & $\begin{array}{l}\text { Stakeholders' engagement factors are not relevant in determining timely completion of building } \\
\text { project in public tertiary institutions in Bauchi and Gombe state, Nigeria. }\end{array}$
\end{tabular}

\section{Conceptual Framework of the Study}

A conceptual framework is a schematic or pictorial relationship of the study variables, according to Oso and Onen [20] they are scheme of concepts operationalized in order to achieve the stated objectives. The scheme in figure 1 is the proposed framework which shows the relationship between the independent and dependent variables of the study. The framework proposed that timely completion of building projects in public tertiary institutions in Bauchi and Gombe state, Nigeria is dependent on effective management: prioritization of activities, delegation of responsibilities, scheduling of activities, managing time wasters and monitoring, controlling and evaluation of project progress. effective public procurement procedures: due process in award of contract, availability of finance, construction/procurement method, and transparency and accountability. stakeholder's engagement input: communication and teamwork, planning, involvement of stakeholders and identification of purpose. Thus, which are the independent variables of the study respectively.

\section{Determinants}

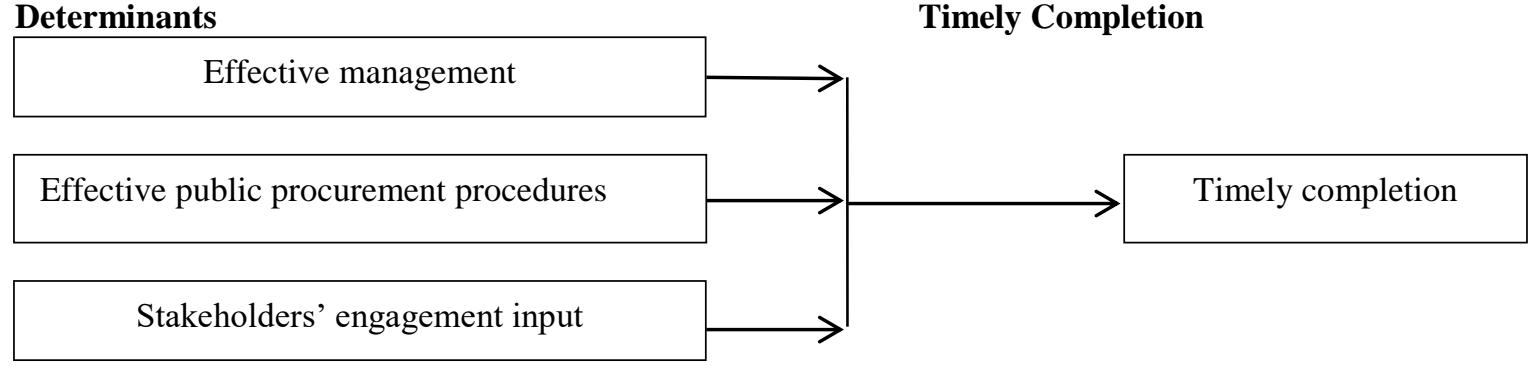

Independent Variables

Figure 1: Conceptual framework

Dependent Variable

Source: Author 


\section{A Principle Framework for Determining Timely Completion of Building Projects in Public Tertiary Institutions in Bauchi and Gombe State, Nigeria}

\section{METHODOLOGY}

A descriptive survey method was used in this study, which is a quantitative research design. it is an inquiry into a social or human problem, based on testing a theory composed of variables, measured with numbers, and analyzed with statistical procedures, in order to determine whether the predictive generalizations of the theory holds true [21]. In addition, an intensive review of literature was carried out, literature review forms the basis upon which a research study is built [20], and questionnaire was used as the appropriate instrument or tool to collect data [22]. The questionnaire was designed with a six-point Likert scale viz. 1- Not Relevant to 6- Most Relevant; 1-completely disagree to 6- Completely Agree. Lodico et al., [22] the Likert scale is the most widely used scale in survey research and certainly the one that has found its way into popular culture. Content of the tool was validated, one of the most commonly used indicators for internal consistency reliability is using Cronbach's coefficient alpha [23]. Reliability refers to an instrument's ability to consistently produce the same results for an individual over time while validity focuses on ensuring that what the instrument claims to measure is what it truly measures [22];[24].

A total of 170 questionnaires were distributed using stratified random sampling technique to four public tertiary institutions in Bauchi and Gombe state all located in North-Eastern Nigeria viz. Abubakar Tafawa Balewa University Bauchi (ATBU), Federal Polytechnic Bauchi (FEDPOLY), Federal University of Kashere (FUK) and Federal College of Education Technical Gombe (FCET). The institutions were selected due to high concentration of building projects funded by the federal government agencies. The respondents of the study are clients, consultants and contractors been ably represented by management and construction professionals like Architects, Builders, Quantity surveyors, Engineers, Project managers, Planners/Estate surveyors. SPSS Software was used to carry out descriptive and inferential analysis in the form of frequencies, percentages, mean scores, standard deviation, regression and one sample T-test for the research questions and hypotheses respectively.

\section{RESULTS AND DISCUSSION}

Table 3 : Questionnaire Response Analysis

\begin{tabular}{lccccc}
\hline Respondents & $\begin{array}{c}\text { Distribution } \\
(\text { No) }\end{array}$ & $\begin{array}{c}\text { Distribution } \\
(\%)\end{array}$ & $\begin{array}{c}\text { Returned } \\
(\text { No) }\end{array}$ & $\begin{array}{c}\text { Suitably } \\
\text { Retrieved (No) }\end{array}$ & $\begin{array}{c}\text { Suitably Retrieved } \\
(\%)\end{array}$ \\
\hline ATBU & 45 & 26.5 & 26 & 24 & 27.0 \\
FEDPOLY & 40 & 23.5 & 21 & 16 & 18.0 \\
FUK & 45 & 26.5 & 31 & 29 & 33.0 \\
FCET & 40 & 23.5 & 25 & 20 & 22.5 \\
\hline Total & 170 & 100 & 103 & 89 & \\
\hline
\end{tabular}

Source: Author

Table 3 shows that a total of 170 questionnaires were distributed of which One hundred and three (103) questionnaires equivalent to $60.59 \%$ were returned. However, only 89 representing $(52.35 \%)$ were found suitable for the analysis. Thus, of the questionnaires returned $14(8.24 \%)$ were spoiled or not suitable due to errors. As such, the study attains $60.59 \%$ response rate.

Table 4: Reliability Test Result of Determinants

\begin{tabular}{llll}
\hline Variable/Factors & No. of items & Cronbach's alpha (a) & Remark \\
\hline Effective management & 5 & 0.803 & Reliable \\
Effective public procurement procedures & 4 & 0.757 & Reliable \\
Stakeholders' engagement input & 4 & 0.795 & Reliable \\
\hline
\end{tabular}

Source: Author

Table 4 above present the internal consistency test of the study variables. An alpha value less than $0.6(\alpha<$ $0.6)$, indicates unsatisfactory internal consistency reliability [25].
However, for this study all the three variables measured satisfactorily because their values are above 0.60 alpha ranges. Hence, they are all reliable for this study. 


\section{A Principle Framework for Determining Timely Completion of Building Projects in Public Tertiary Institutions in Bauchi and Gombe State, Nigeria}

\section{Bio Data of Respondents}

Table 5 above shows the background information of the respondents. Findings revealed that all the critical stakeholders in a typical building project were duly represented with: $43.8 \%$ client; $25.8 \%$ for the consultants and $30.3 \%$ claimed to be affiliated with the contractors. As such, there was low probability of biasness of any sort from the data obtained. All the major professional stakeholders like in Engineering, Quantity surveying, Architecture, Building technology, Project management and Planning and estate surveying were adequately represented in the study. As such, their perception is more reliable. Majority of the respondents have the requisite academic qualifications with $57.3 \%$ having Bachelor Degree/Higher National Diploma; $36 \%$ claimed to possessed Master-degree/Post Graduate Diploma. All the respondents have the requisite years of working in building projects with $23.6 \%$ having $1-5$ years; $61.8 \%$ claimed to have $6-15$ years working experience while $14.6 \%$ reported to have more than 15 years working experience. As such, the participants in the survey are well experienced which increased reliability of the data obtained. Virtually all the respondents have experienced delay in timely completion of the building projects they were involved, with majority $61.8 \%$ reporting $1-12$ months delay, $12.4 \%$ reported experiencing more than 18 months delay while $7.9 \%$ claimed not to have experienced delay in timely completion. As such, time overrun is still a major phenomenon in need of remedy in building projects in public tertiary institutions in Bauchi and Gombe state, Nigeria.

Table 5: Participants Background Information

\begin{tabular}{l|lcc}
\hline Classifications & Characteristics & Frequency (No) & Percentage (\%) \\
\hline Working Affiliation & Client & 39 & 43.8 \\
& Consultants & 23 & 25.9 \\
& Contractors & 27 & 30.3 \\
& Total & $\mathbf{8 9}$ & $\mathbf{1 0 0 . 0}$ \\
& Project Management & 6 & 6.7 \\
& Architecture & 15 & 16.9 \\
& Engineering & 22 & 24.7 \\
& Quantity surveying & 20 & 22.5 \\
& Building Technology & 13 & 14.6 \\
Highest Academic Qualification & Planning/Estate surveying & 13 & 14.5 \\
& Total & $\mathbf{8 9}$ & $\mathbf{1 0 0 . 0}$ \\
& NCE / ND & 2 & 2.2 \\
& Degree/HND & 51 & 57.3 \\
& Masters/PGD & 32 & 36.0 \\
& PhD & 4 & 4.5 \\
& Total & $\mathbf{8 9}$ & $\mathbf{1 0 0 . 0}$ \\
& 1-5 years & 21 & 23.6 \\
& 6-10 years & 34 & 38.2 \\
& $11-15$ years & 21 & 23.6 \\
& More than 15 years & 13 & 14.6 \\
Experienced delay completion & Total & $\mathbf{8 9}$ & $\mathbf{1 0 0 . 0}$ \\
& Yes & 82 & 92.1 \\
& No & 7 & 7.9 \\
& Total & $\mathbf{8 9}$ & $\mathbf{1 0 0 . 0}$ \\
& 0 months & 7 & 7.9 \\
& 1-6 months & 29 & 32.6 \\
& 6-12 months & 33 & 37.1 \\
& 12-18 months & 9 & 10.1 \\
& more than 18 months & 11 & 12.4 \\
& Total & $\mathbf{8 9}$ & $\mathbf{1 0 0 . 0}$ \\
\hline
\end{tabular}

Source: Author 
A Principle Framework for Determining Timely Completion of Building Projects in Public Tertiary Institutions in Bauchi and Gombe State, Nigeria

What are the principle factors determining timely completion of building projects in in public tertiary institutions in Bauchi and Gombe state, Nigeria?

Table 6: Determining Factors of Timely Completion

\begin{tabular}{|c|c|c|c|}
\hline Factors & Mean & Std. Dev. & Rankings \\
\hline - Communication and teamwork & 4.76 & 1.22 & $1^{\mathrm{st}}$ \\
\hline - Monitoring and evaluation & 4.63 & 1.25 & $2^{\text {nd }}$ \\
\hline - Planning & 4.56 & 1.27 & $3^{\text {rd }}$ \\
\hline - Due process in award of contract & 4.54 & 1.25 & $4^{\text {th }}$ \\
\hline - Involvement of stakeholders & 4.51 & 1.11 & $5^{\text {th }}$ \\
\hline - Due availability of finance & 4.49 & 1.14 & $6^{\text {th }}$ \\
\hline - Suitable construction/procurement method & 4.46 & 1.13 & $7^{\text {th }}$ \\
\hline - identification of purpose & 4.46 & 1.15 & $7^{\text {th }}$ \\
\hline - ensuring transparency and accountability in processes & 4.42 & 1.39 & $9^{\text {th }}$ \\
\hline - effective daily/weekly scheduling & 4.35 & 1.30 & $10^{\text {th }}$ \\
\hline - Delegation of activities responsibilities & 4.35 & 1.23 & $11^{\text {th }}$ \\
\hline - Prioritization of activities & 4.29 & 1.27 & $12^{\text {th }}$ \\
\hline - Managing time wasters & 3.98 & 1.28 & $13^{\text {th }}$ \\
\hline Grand mean & 4.45 & & \\
\hline
\end{tabular}

Source: Author

Table 6 shows determining factors of timely completion of building projects in public tertiary institutions. It presents the mean scores, standard deviation and ranking of the factors. Findings revealed that all the factors were rated as relevant by the respondents having scored more than 3.00 above average in a 6-point Likert scale of relevancy used in this study. In addition, the most ranked are: Communication and teamwork (Mean "M" 4.76 and Standard Deviation "SD" 1.22) was ranked "first". Monitoring and evaluation (M 4.63 \& SD 1.25) were ranked "second". Planning (M 4.56 \& SD 1.27) was ranked as the "third" most relevant determinant factor. Due process in award of contract (M 4.54 \& SD 1.25) was ranked as the "fourth" most relevant determining factor. Involvement of stakeholders (M 4.51 \& SD 1.11) was ranked as the "fifth" most relevant factor. Due availability of finance (M 4.49 \& SD 1.14) was ranked "sixth". While suitable construction/procurement method and identification of purpose, with mean scores 4.46 each and Standard deviation 1.13 \& 1.15 were ranked "seventh" respectively. However, the least ranked determinant was: managing time wasters (M 3.98 \& SD 1.28) ranked "thirteenth".

In your opinion, is timely completion of building projects in public tertiary institutions in Bauchi and Gombe state, Nigeria an indicator of project success?

Table 7: Perception of Timely Completion as Indicator of Project Success

\begin{tabular}{l|cccccc}
\hline Rating scale & $\begin{array}{c}\text { Completely } \\
\text { Disagree }\end{array}$ & $\begin{array}{c}\text { Mostly } \\
\text { Disagree }\end{array}$ & $\begin{array}{c}\text { Slightly } \\
\text { Disagree }\end{array}$ & $\begin{array}{c}\text { Slightly } \\
\text { Agree }\end{array}$ & $\begin{array}{c}\text { Mostly } \\
\text { Agree }\end{array}$ & $\begin{array}{c}\text { Completely } \\
\text { Agree }\end{array}$ \\
\hline Frequency (No) & 1 & 2 & 3 & 3 & 32 & 48 \\
Percentage (\%) & 1.1 & 2.2 & 3.4 & 3.4 & 36.0 & 53.9 \\
\hline
\end{tabular}

Source: Author

Table 7 above shows that in a 6-point Likert scale rating, findings revealed that $89.9 \%$ of the respondents are in strong agreement that timely completion is an important indicator of assessing the success of building projects in public tertiary institutions, while 6 respondents $(6.7 \%)$ are in disagreement in favour of other performance indicators.

To what extent does the principle determining factors influences timely completion of building project in public tertiary institutions in Bauchi and Gombe state, Nigeria? 


\section{A Principle Framework for Determining Timely Completion of Building Projects in Public Tertiary Institutions in Bauchi and Gombe State, Nigeria}

Table 8: Regression Model Summary

\begin{tabular}{lcccc}
\hline Model & R & R Square & Adjusted R Square & Std. Error of the Estimate \\
\hline 1 & $.218^{\mathrm{a}}$ & .048 & $\mathbf{. 0 3 7}$ & $\mathbf{. 9 7 9 0 0}$ \\
\hline
\end{tabular}

a. Predictors: (Constant), Principle Determinants- effective management, Public procurement procedures, stakeholders engagement input

Table 8 is the regression model summary of the independent variable i.e. principle determinants. It shows the multiple correlations $\mathrm{R}$-Value of 0.218 which is fair for this type of study and R-Square value of 0.048 which explains $4.8 \%$ of the variance $(0.048 \mathrm{x}$
$100 \%$ ) and the adjusted R-Square 0.037. The error of estimate 0.979 is quite low. As such, there was evidence that the data used in analyzing the relationship between the independent variables and timely completion were closely related.

Table 9: ANOVA ${ }^{\mathrm{b}}$ Statistics

\begin{tabular}{llccccc}
\hline \multicolumn{1}{l}{ Model } & Sum of Squares & df & Mean Square & F & Sig. \\
\hline 1 & Regression & 4.166 & 1 & 4.166 & 4.347 & $.040^{\mathrm{a}}$ \\
& Residual & 83.384 & 87 & .958 & & \\
& Total & 87.551 & 88 & & & \\
\hline
\end{tabular}

a. Predictors: (Constant), Principle Determinants- effective management, public procurement procedures, stakeholders' engagement input

b. Dependent Variable: Timely completion

Table 9 present the ANOVA which tests the acceptability of the model from a statistical perspective. The independent variable i.e. the principle determinants in this model accounts for 4.17 variations, though 83.38 was unaccounted. However, [F $(1,87)=4.347]$, Sig. 0.04 is less than P-value of 0.05 which means the variation explained by the model is significant and was not due to chance. The implication is that the model for this study is statistically significant in predicting how the principle determining factors can influence timely completion of building projects in public tertiary institutions in Bauchi and Gombe state, Nigeria.

Table 10: Regression Coefficients ${ }^{\mathrm{a}}$ of Principle Determinants and Timely Completion

\begin{tabular}{|c|c|c|c|c|c|c|}
\hline & \multirow{2}{*}{ Model } & \multicolumn{2}{|c|}{ Unstandardized Coefficients } & \multirow{2}{*}{$\begin{array}{c}\begin{array}{c}\text { Standardized } \\
\text { Coefficients }\end{array} \\
\text { Beta }\end{array}$} & \multirow[b]{2}{*}{$\mathbf{T}$} & \multirow[b]{2}{*}{ Sig. } \\
\hline & & B & Std. Error & & & \\
\hline \multirow[t]{2}{*}{1} & (Constant) & 4.240 & .531 & & 7.988 & .000 \\
\hline & $\begin{array}{l}\text { Determining } \\
\text { Factors }\end{array}$ & .019 & .009 & .218 & 2.085 & .040 \\
\hline
\end{tabular}

a. Dependent Variable: timely completion

Table 10 presents the linear regression analysis coefficient of the influences of the independent variables i.e. determining factors on timely completion which is the dependent variable. Findings revealed that if all the other variables are kept constant, a unit increase in effective management, effective public procurement procedures and stakeholder's engagement input will lead to $21.8 \%$ (Beta " $\beta$ " = 0.218) causeeffects increased on timely completion of building projects in public tertiary institutions in Bauchi and Gombe state, Nigeria. In addition, at 5\% level of significance and 95\% level of confidence $[t=2.085]$ is Sig. $0.040<0.05$ i.e. the P-value. As such, the independent variables were significant in affecting timely completion of building project in public tertiary institutions in Bauchi and Gombe state, Nigeria. 


\section{A Principle Framework for Determining Timely Completion of Building Projects in Public Tertiary Institutions in Bauchi and Gombe State, Nigeria}

\subsection{Test of Hypotheses}

The following are the Null hypotheses and alternate hypotheses proposed for this framework.

$\boldsymbol{H}_{\boldsymbol{0}}$ Effective management, effective public procurement procedures and stakeholders' engagement inputs are not relevant in determining timely completion of building projects in public tertiary institutions in Bauchi and Gombe state, Nigeria.

$\boldsymbol{H}_{\boldsymbol{A}}$ Effective management, effective public procurement procedures and stakeholders' engagement inputs are relevant in determining timely completion of building construction projects in public tertiary institutions in Bauchi and Gombe state, Nigeria

Table 11: Hypothesis Test Analysis

\begin{tabular}{|c|c|c|c|c|c|c|}
\hline \multirow{3}{*}{ Principle determining factors } & \multicolumn{6}{|c|}{ Test Value $=4.25$} \\
\hline & \multirow[b]{2}{*}{$\mathbf{T}$} & \multirow[b]{2}{*}{ Df } & \multirow{2}{*}{$\begin{array}{c}\text { Sig. } \\
\text { (2-tailed) }\end{array}$} & \multirow{2}{*}{$\begin{array}{c}\text { Mean } \\
\text { Difference }\end{array}$} & \multicolumn{2}{|c|}{$\begin{array}{c}95 \% \text { Confidence Interval } \\
\text { of the Difference }\end{array}$} \\
\hline & & & & & Lower & Upper \\
\hline Effective Management & 34.608 & 88 & .000 & 17.34551 & 16.3495 & 18.3415 \\
\hline Public Procurement procedures & 34.258 & 88 & .000 & 13.66011 & 12.8677 & 14.4525 \\
\hline Stakeholders' engagement input & 35.457 & 88 & .000 & 14.04213 & 13.2551 & 14.8292 \\
\hline
\end{tabular}

Source: Author

Table 11 present the hypotheses test results of this study using one-sample T-Test. The test value of 4.25 been the grand mean of the principle determining factors calculated was considered. Also, Kolmogorovsaminov test of normality was used to confirm the suitability of the data. Findings revealed that all the principle determinants: effective management, effective public procurement procedures, stakeholders' engagement input with significance value of 0.000 each, and are less than the critical significance level of 0.05 at $95 \%$ confidence interval. Since the calculated pvalues are all less than 0.05 with $t$-values $=34.608$, 34.258 and 35.457 respectively, the null hypothesis which states that effective management, effective public procurement procedures and stakeholders' engagement inputs are not relevant in determining timely completion of building projects in public tertiary institutions in Bauchi and Gombe state, Nigeria are here by rejected. Hence, due to the statistical significance $0.000<0.05$ critical P-value, effective management, effective public procurement procedures and stakeholders' engagement inputs factors are relevant in determining timely completion of building projects in public tertiary institutions in Bauchi and Gombe state, Nigeria. Therefore, the null hypotheses are rejected and the alternate hypotheses are hereby confirmed.

\section{DISCUSSION OF FINDINGS}

A major finding of this study was that $90 \%$ of the respondents are in strong agreement that timely completion is an essential indicator in assessing the success of building projects in public tertiary institutions. Effective management factors such as monitoring and evaluation are essential in determining timely completion of building projects in public tertiary institutions in Bauchi and Gombe state, and the findings was in agreement with similar findings in studies made by [2];[8];[26];[27] respectively. However, in a contrary opinion from the study outcome, managing time wasters during building project activities like frequent social media chatting, receiving unscheduled visitors, doing delegable activities among others nowadays should be a key determinant of timely completion of building construction projects. Effective public procurement procedures with factors such as ensuring due process in award of contract, due availability of finance, and suitable construction/procurement method are essential in determining timely completion of building projects in public tertiary institutions in Bauchi and Gombe state and the findings was concurred by [3];[28];[29];[25]; [11];[16] in their various studies respectively. According to Bizon-Gorecka and Gorecki [30] the relations of stakeholders are very important and significant at each project execution stage. As such, in building projects most especially in public tertiary 


\section{A Principle Framework for Determining Timely Completion of Building Projects in Public Tertiary Institutions in Bauchi and Gombe State, Nigeria}

institutions engaging stakeholders through planning, identification of purpose, and continuous communication and teamwork from the project initiation to its closure is a key relevant determinant of timely completion and this assertion was in line with similar findings by [19];[28];[31];[29];[32] in their studies respectively. The implication of these results is that the principle determinant factors viz. effective management, effective public procurement procedures and stakeholders' engagement inputs will lead to $21.8 \%$ increase cause-effects on timely completion of building projects in public tertiary institutions in Bauchi and Gombe state, Nigeria.

\section{CONCLUSION AND RECOMMENDATIONS}

The aim of the study was to proposed a principle framework for determining timely completion of building projects in public tertiary institutions in Bauchi and Gombe State, Nigeria. A total of 170 sample questionnaires were randomly distributed to respondents from four public tertiary institutions. Timely completion is an essential indicator in assessing the success of building projects in public tertiary institutions. This study assessed thirteen (13) factors determining timely completion of building projects in public tertiary institutions with: communication and teamwork, monitoring and evaluation, planning, due process in award of contract, involvement of stakeholders, due availability of finance, suitable construction/procurement method, and identification of purpose been the most important.

The implication of this study is that effective management, effective public procurement procedures and stakeholders' engagement inputs are the principle determinants of timely completion of building projects in public tertiary institutions in Bauchi and Gombe state, Nigeria with $21.8 \%$ increase cause-effects in reducing time overrun. In light of the conclusion, the followings are recommended.

a) To ensure success in timely completion of building projects in public tertiary institutions there is need for managerial synergy between the contractors, consultants and the client through monitoring and evaluation, and proper scheduling of activities.

b) Proper adherence with led down public procurement procedures should be ensured at all times in the execution of building projects in public tertiary institutions in Nigeria.

c) Stakeholders such as project sponsors, benefiting institutions, end-users, communities, project consultants and contractors among others should be engaged adequately throughout the stages of the building projects in public tertiary institution in Nigeria to ensure timely completion.

\section{ACKNOWLEDGEMENT}

I wish to extend my profound gratitude to the management and editorial team of BJoST, all the reviewers and respondents who participated and make this study and publication a reality.

\section{REFERENCES}

[1] Bowen, P., Cattel, K., Edwards, P., \& Pearl, R. (2012). Perceptions of Time, Cost and Quality Management on Building Projects. Australasian Journal of Construction Economics and Building. 2(2):48-56. 10.5130/ajceb.v2i2.2900.

[2] Shehu, S., Zadawa, A. N., Waziri, A. Y \& Shehu, R. (2020). Adherence with the Processes of Time Management in Construction Project Delivery in Nigeria. Borneo Journal of Social Science \& Humanities. DOI: https://doi.org/10.35370/

bjssh.2.1-08.

[3] Murithi, S. H., Makokha, E. N., \& Otieno, C. (2017). Factors Affecting Timely Completion of Public Construction Projects in Trans-Nzoia County. International Journal of Scientific and Research Publications, 7(4):404-434.

[4] Jagboro, D., \& Ogunsemi, G. (2006). Time-cost model for Building projects in Nigeria. Construction Management and Economics, 253-258.

[5] Abdullahi, N.Z., Gambo, N., \& Mohammad, S.A (2019). A framework for ethical procurement of construction projects in Nigerian Federal Universities. IOP Conf. Ser.: Mater. Sci. Eng. 615 012026.

[6] Fayomi, I. O. (2013). Public procurement and due process policy in Nigeria: Thrust, prospects and challenges Peak J. of Social Sciences and Humanities 1(4):39-45.

[7] De Araújo, M.C.B., Alencar, L.H. \& Mota, C.M.D. (2017). Project procurement management: A structured literature review. Int. J. Proj. Manag. http://dx.doi.org/10.1016/ j.ijproman.

[8] Adeagbo, D.O., Mohammed, S. \& Abdulkadir, S. (2019). Principles of Management Application in Building Construction Projects: Perspectives of Project Managers'. Path of Science. DOI: 10.22178/pos.53-7. 5(12) 4001-4007.

[9] Shehu, S. (2021). A Review of Time Management Factors in Construction Project Delivery. Journal of Project Management and Practice. 1(2):34-45

[10] Gambo, S., Ibrahim, K., Iliyasu, M.A., Shakantu, W.M.W \& Ibrahim, M.L. (2017). Stakeholders' Perception of the Success of Tertiary Education Fund Construction Projects. Atbu Journal of Environmental Technology. 10(2):117-128 
[11] Kariungi, S.M. (2014). Determinants of Timely Completion of Projects in Kenya: A Case of Kenya Power and Lighting Company, Thika. ABC Journal of Advanced Research, 3(2)9.

[12] National University Commission [NUC] (2021). www.nuc.gov.ng.

[13] Bauchi, and Gombe State (2021). Ministry of Education Archive. Bauchi, and Gombe state Government. Federal Ministry of Education (2021). www.fmed.gov.ng.

[14] Block, K.M., \& Peterson, D. E. (2015) Construction Scheduling: The Key to Timely Completion. New York law journal, www.nylj.com, ALM publisher. Vol. 253 No. 115.

[15] Bashir, K.T. \& Akinola, G.A (2019). Assessment of factors influencing the use of advance payment on building projects in Lagos, Nigeria. The quantity surveyor -Journal of Nigeria institute of quantity surveyors. http://journal.niqs.org.ng. 65(1-2):6-13.

[16] Chartered Institute of Building [CIOB] (2010). A Report Exploring Procurement In The Construction Industry. Chartered institute of building. www.ciob.org.

[17] Project Management Institute (PMI). (2017). A guide to the Project Management Body of Knowledge (PMBOK Guide) 6th Edt. Newtown Square, PA 19073-3299 USA: Project Management Institute, Inc.

[18] United Nation Development Programme (UNDP). (2009). Hand book on planning, monitoring and evaluating for development results: united nation development programme. New York: one United Nations plaza/www.undp.org/eo/handbook.

[19] Kobusingye, B., Mungatu, J. K. \& Mulyungi, P. (2017). Influence of Stakeholders Involvement on Project Outcomes. A Case of Water, Sanitation, and Hygiene (Wash) Project in Rwanda. European Journal of Business and Social Sciences, 6(6):195206.

[20] Oso, W. Y., \& Onen, D. (2011). Writing research proposal and report: A handbook for beginning Researchers, Rsvd edn. Nairobi-Kenya: The Jomo Kenyatta Foundation

[21] Creswell, J.W. (1994). Research design: qualitative and quantitative approaches. Sage Publishers, Thousand Oacks, California.

[22] Lodico, M.G., Spaulding, D.T., \& Voegtle, K.H. (2006). Methods in Educational Research: From Theory to Practice. Jossey-Bass A Wiley Imprint 989 Market Street, San Francisco, CA 94103-1741 www.josseybass.com.
[23] Pallant, J. (2001). SPSS survival manual: A step by step guide to data analysis using SPSS for Windows (Version 10). Allen \& Unwin. www.allenandunwin.com/spss.htm.

[24] Kothari, C. R. (2004). Research methodology: Methods and Techniques (2 $\left.{ }^{\text {nd }}\right)$ Rev. Ed. New age international (p) Ltd. 4835/24, Ansari Road, Daryaganj, New Delhi - 110002. www.newagepublishers.com.

[25] Jeptepkeny, P. (2015). Effects of Procurement Procedures on Project Performance: A Case Study of Light Construction Projects at Kenya Ports Authority, Mombasa. European Journal of Logistics Purchasing and Supply Chain Management. 3(1):111.

[26] Hoseini, E. (2015) Project Time Planning in Norwegian Construction Industry: An Empirical Study. A Published Master Thesis, Norwegian University of Science and Technology.

[27] Okoye, P. U., Ngwu, C., \& Ugochukwu, S. C. (2015). Evaluation of Management Challenges Facing Construction Practice in Nigeria. International Journal of Application or Innovation in Engineering \& Management. 4(1).

[28] Akhund, M. A., Khoso, A.R., Memon, U. \& Khahro, S.H (2017). Time Overrun in Construction Projects of Developing Countries. Imperial Journal of Interdisciplinary Research. 3(4):1-6.

[29] Amade, B., Ubani, E. C., Omajeh, E. O.-M., \& Njoku, U. A. (2015). Critical Success Factors for Public Sector Construction Project Delivery: A Case of Owerri, Imo State. International Journal of Research in Management, Science \& Technology. 3(1):11-21.

[30] Bizon-Gorecka, J., \& Gorecki, J. (2017). Influence of Selected Stakeholders of Construction Investment Projects on the Course of Project. IOP Conf. Series: Materials Science and Engineering 245. doi:10.1088/1757-899X/245/7/072018 pp. 1-7). IOP Publishing.

[31] Ayodeji, O., Eseohe, A., Opeyemi, J., Ebenezer, B., Amusan, L., \& Abisola, O. (2017). Project Management A Panacea to Improving The Performance of Construction Projects In Ogun State, Nigeria. International Journal of Civil Engineering and Technology, 8(9):1234-1242.

[32] Wong, K., \& Vimonsatit, V. (2012) A study of the factors affecting construction time in Western Australia. Scientific Research and Essays. 7(40):3390-3398. 